\title{
Metabolism of the preimplantation embryo: 40 years on
}

\author{
Henry J Leese \\ Hull York Medical School, Centre for Cardiovascular and Metabolic Research, University of Hull, Hertford Building, \\ Cottingham Road, Hull HU6 7RX, UK
}

Correspondence should be addressed to H J Leese; Email: henry.leese@hyms.ac.uk

\begin{abstract}
This review considers how our understanding of preimplantation embryo metabolism has progressed since the pioneering work on this topic in the late 1960s and early 1970s. Research has been stimulated by a desire to understand how metabolic events contribute to the development of the zygote into the blastocyst, the need for biomarkers of embryo health with which to improve the success of assisted conception technologies, and latterly by the 'Developmental Origins of Health and Disease' (DOHaD) concept. However, arguably, progress has not been as great as it might have been due to methodological difficulties in working with tiny amounts of tissue and the low priority assigned to fundamental research on fertility and infertility, with developments driven more by technical than scientific advances. Nevertheless, considerable progress has been made in defining the roles of the traditional nutrients: pyruvate, glucose, lactate, and amino acids; originally considered as energy sources and biosynthetic precursors, but now recognized as having multiple, overlapping functions. Other nutrients; notably lipids, are beginning to attract the attention they deserve. The pivotal role of mitochondria in early embryo development and the DOHaD concept, and in providing a cellular focus for metabolic events is now recognized. Some unifying ideas are discussed; namely 'stress-response models' and the 'quiet embryo hypothesis'; the latter aiming to relate the metabolism of individual preimplantation embryos to their subsequent viability. The review concludes by updating the state of knowledge of preimplantation embryo metabolism in the early 1970 s and listing some future research questions.

Reproduction (2012) 143 417-427
\end{abstract}

\section{Introduction}

The basic pattern of metabolism in the early mammalian embryo was established in the late 1960s and early 1970s. The key figure in this endeavor was John Biggers working successively at the University of Philadelphia, The Johns Hopkins University and Harvard Medical School; other notable contributors included his graduate students Ralph Brinster and David Whittingham, and colleagues Ray Wales and Wesley Whitten.

The state of knowledge at that time was wellsummarized by Biggers \& Stern (1973) in a review entitled 'Metabolism of the preimplantation embryo' and in an article published the same year by Brinster (1973), Nutrition and metabolism of the ovum, zygote and blastocyst'. In this review, Brinster provided the following description:

Pyruvate appears to be the central energy substrate in those species (mouse, rabbit and monkey) in which energy source requirements of the embryo have been examined. During the first day or two of the embryo's life, the Embden-Meyerhoff pathway (glycolysis) has a very low capability, but after blastocyst formation there is a sharp increase in glycolytic ability. The Krebs cycle is the main source of energy throughout the preimplantation period. Large increases in oxygen consumption and uptake and incorporation of carbon occur at about the time of blastocyst formation. The embryo goes from a relatively inactive metabolic tissue at ovulation to a rapidly metabolizing tissue at implantation.

Almost 40 years on, this succinct statement remains remarkably accurate; a testimony to the pioneers mentioned above. However, arguably, fundamental research on metabolism in early embryos has not advanced as fast as it might have done. One reason is methodological; despite being the largest cells in the female mammal, eggs and preimplantation embryos are available in small numbers only and in the case of the human, their quality is poor and there are ethical constraints in many countries. Thus, techniques (e.g. for studying enzymology, signal transduction, and embryo proteomics) developed for somatic tissue, where the numbers of cells, by comparison, are virtually limitless are insufficiently sensitive for oocytes and early embryos.

Secondly, although there has been a long search for biomarkers of embryo viability with which to improve the success of assisted reproductive technologies, which 
has provided some stimulus to research, developments in human and animal assisted conception have tended to be driven by technical advances rather than fundamental science (Leese \& Wittall 2001). As recorded in O'Brien et al. (1999):

Advances in assisted conception techniques are being introduced into the clinic before the basic scientific work on how they affect early embryonic development has been carried out.

The statement was made at a Study Group convened in by the Royal College of Obstetricians and Gynaecologists to consider: 'Fetal Programming: Influences on Development and Disease in Later Life'. This area of biology, which began as the 'Fetal Origins' hypothesis of Barker (O'Brien et al. 1999), was extended to encompass pre- and periconceptual events and then to the whole time-span of development - whereby conditions (especially nutritional) during early stages in the life-scale can potentially impact on events in later life. As a result, this field of study is now termed: the Developmental Origins of Health and Disease $(\mathrm{DOHaD})$. The reason for this digression is to point out that the DOHaD concept has provided a welcome stimulus to studies in reproductive biology and to human and animal nutrition; indeed, reproductive biologists and nutritionists owe a great debt to Barker (2004) for throwing this lifeline to their respective disciplines which have not been perceived historically as priority areas within the scientific and clinical establishments and have not attracted the funding they deserve.

DOHaD-inspired studies have also contributed to the notion that changes in embryo phenotype, including metabolic, following exposure to novel environments are to a major extent, mediated by epigenetic modification and that there is considerable metabolic plasticity (Chason et al. 2011). This appreciation - that epigenetic changes are crucial for normal early development in mammals - is one example of the wider discipline of 'Ecological developmental biology' which provides a valuable framework for studying the means by which environmental factors alter phenotype at all levels of organization, including the whole organism, in animals and plants (Gilbert \& Epel 2009). DOHaD issues are now centre-stage and the subject of numerous reports; highly recommended is an authoritative survey by the UK Scientific Advisory Committee on Nutrition (SACN 2011) entitled: 'The influence of maternal, fetal and child nutrition on the development of chronic disease in later life', which delves deeply into the evidence base underlying our understanding of these complex issues.

A further area that has recently brought embryo metabolism to a wider scientific community is that of embryonic stem (ES) cells, which, of course, originate in the inner cell mass (ICM) of the blastocyst. The extent to which the metabolism of ES cells mirrors that of the ICM and changes with differentiation is a subject of debate (Birket et al. 2011, Varum et al. 2011).

\section{Animal models}

Before considering the ways in which metabolism has developed as a subject of enquiry in early embryos it is useful to consider briefly the main animal models that have been used in research.

The standard model for studying preimplantation development has been the mouse, which, especially for unraveling developing mechanisms has been unrivaled, with inbred strains providing large numbers of highly homogeneous zygotes, virtually all of which, in skilled hands, will develop into blastocysts. As well as providing a robust model for studying metabolism and its relationship with development, the mouse embryo has provided an exquisite system for testing the effect of dietary or environmental perturbations on future development and contributing to understanding the $\mathrm{DOHaD}$ concept. However, this strength is also the major weakness of the mouse model metabolically in that it is especially vulnerable to changes in nutrient provision compared with the oocytes and embryos of domestic animals and most likely of man. This is starkly illustrated by experiments in which oocytes or embryos are deprived of nutrients and their subsequent development monitored. For example, Downs \& Hudson (2000) found that mouse oocytes arrested within $15 \mathrm{~h}$ of culture under such conditions and Manser and Leese (cited in Ferguson \& Leese (2006)) reported a similar finding for mouse zygotes, which degenerated within $10 \mathrm{~h}$. By contrast, rabbit zygotes can complete three cleavage divisions in the complete absence of nutrients (Kane 1987); with analogous results for cattle zygotes reported by Ferguson \& Leese (2006). Sturmey et al. (2009a) accounted for these data in terms of the high endogenous energy; especially, fat content, of the embryos of these large animals, building on earlier work by Kane (1979). Thus, pig oocytes contain $37.3 \mathrm{ng} \mathrm{fat} / \mathrm{nl}$ volume of oocyte, sheep, $21.2 \mathrm{ng}$ and cow $15 \mathrm{ng}$ compared with 6.25 in the mouse. These differences are reflected at the whole-body level with mice consuming about $120 \mathrm{~g}$ food $/ \mathrm{kg}$ of their body weight per day compared with about $6 \mathrm{~g} / \mathrm{kg}$ in man. This makes mice and other rodents vulnerable to dietary modification.

In summary, studies on mouse embryos have provided the bedrock of our knowledge of preimplantation metabolism and a sensitive indicator of what potentially may go wrong if the early environment of the embryo is perturbed. Considerable caution is required, however, when extrapolating from the mouse to large animals and the human, which by comparison, has an enormous buffering capacity against metabolic insults. Having said this, it is notable that an elevation of blood pressure; one of the best characterized conditions which arise in the offspring of mice following maternal dietary restriction 
during the preimplantation phase (Watkins \& Fleming 2009 ) is replicated in the human, where in a large follow-up study of children conceived through in vitro fertilisation (IVF) (average age 12 years) systolic blood pressure was raised by $6 \mathrm{~mm} \mathrm{Hg}$ (Ceelen et al. 2008).

\section{Energy metabolism}

Metabolism has traditionally been considered as having two functions: the first, to provide the energy required by cells to maintain intracellular homeostasis and support specialized functions; and the second, the provision of metabolites for the biosynthesis of cellular constituents and those destined for export. In the context of the preimplantation embryo, more attention has been devoted to the former than the latter with a focus on the major substrates added to embryo culture media; pyruvate, glucose, lactate, and amino acids.

However, as anticipated in a remarkable, authoritative, review by Barnett \& Bavister (1996) entitled: 'What is the relationship between the metabolism of the preimplantation embryos and their developmental competence?' these distinctions have become blurred since it became apparent that the traditional nutrients have multiple, overlapping functions, and that other nutrients, particularly, lipids, are beginning to attract attention (Sturmey et al. 2006, 2009a, 2009b, Dunning et al. 2010, Jungheim et al. 2011, Van Hoeck et al. 2011, McKeegan \& Sturmey 2012). There is also a welcome interest in downstream events, notably, cell signaling; both intracellular and intercellular. This is a fascinating area since preimplantation embryos exhibit considerable autonomy in vitro and produce their own trophic factors, while engaging in dialog with the female reproductive tract in vivo (Kane et al. 1997, Navarette-Santos 2008). O'Neill (2008) has provided an excellent guide to the molecular complexity involved in these interactions.

These developments are now considered in more detail using as examples, research on oxygen consumption and glucose and amino acid metabolism.

\section{Oxygen consumption}

As stated by Brinster (1973) most of the energy in preimplantation embryos, in the form of ATP, is derived by oxidative metabolism. The general pattern in the preimplantation embryo was established by Fridhandler (1961) for the rabbit, Suguwara \& Umezu (1961) for the rat and Mills \& Brinster (1967) for the mouse. In each case, oxygen consumption was low during cleavage and increased with blastocyst formation; a pattern confirmed over 30 years later by Houghton et al. (1996) (Fig. 1) who also showed that in early postimplantation mouse embryos, oxygen uptake reverts to precavitation levels highlighting the striking need of the blastocyst for ATP to power $\mathrm{Na}^{+}, \mathrm{K}^{+}$ATPase activity required for blastocoels cavity formation (Donnay \& Leese 1999, Houghton

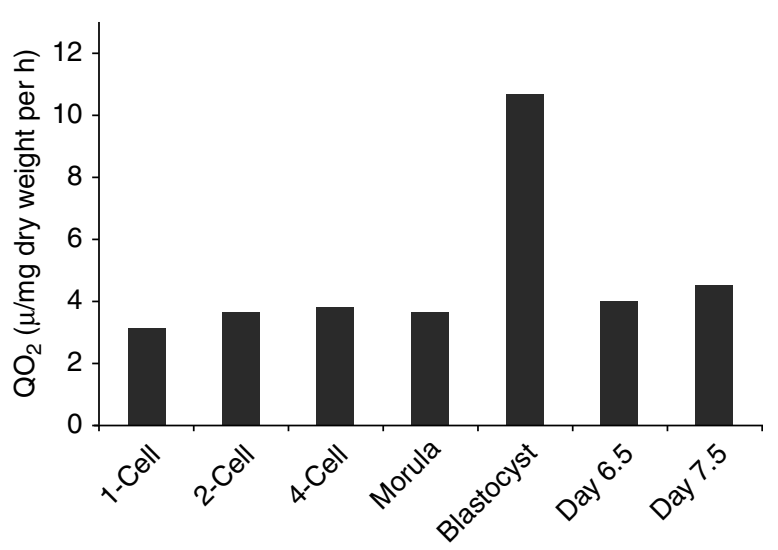

Figure 1 Oxygen consumption by early mouse embryos. Reproduced, with permission, from Houghton FD, Thompson JG, Kennedy CJ \& Leese HJ 1996 Oxygen consumption and energy metabolism of the early mouse embryo. Molecular Reproduction and Development44 476-485.

et al. 2003) and for protein synthesis as the embryo initiates net growth (Leese 1991).

In a significant development, Manes \& Lai (1995) found that $30 \%$ of the oxygen consumed by rabbit blastocysts was due to nonmitochondrial processes; a figure confirmed for mouse blastocysts by Trimarchi et al. (2000) who also reported that in cleavage stage mouse embryos the figure was $\sim 70 \%$. This remarkable finding has gone largely unnoticed. Two candidates for nonmitochondrial oxygen consumption in somatic cells are i) the generation of reactive oxygen species (ROS) via enzymes such as NADPH oxidases; detectable in mouse blastocysts (Manes \& Lai 1995) but not in cleavage stage mouse embryos (Johnson \& Nasr-Esfahani 1994), and xanthine oxidase, not detected during mouse preimplantation development (Alexiou \& Leese 1992, 1994). However, Alexiou \& Leese (1992) showed that purine/ pyrimidine salvage pathways, which can limit ROS formation (Gupta et al. 2006), were active in early mouse embryos. A second candidate is cell surface oxygen consumption (Herst \& Berridge 2007) but this has not been examined in early embryos. The role of high nonmitochondrial oxygen consumption in the preimplantation embryo remains enigmatic.

ROS are very much centre-stage in many areas of biology; from aging to apoptosis. Although formed via enzymes such as those given above, $>95 \%$ of ROS normally arise as by-products of the mitochondrial electron transport chain. ROS have physiological roles; notably in monitoring mitochondrial dysfunction and triggering cell repair processes or apoptosis (Sahin \& DePinho 2010) but 'outside an optimal range result in various developmentally regulated modes of embryo demise' (Bain et al. 2011). ROS are referred to colloquially, as 'friend and foe', for a discussion of which, the reader is referred to an excellent review on mammalian sperm metabolism by Storey (2008). The related topic of reactive nitrogen species in the 
preimplantation embryo has, by contrast, attracted much less attention, though the data of Manser et al. (2004) suggested a physiological role for nitric oxide (NO) in limiting oxygen consumption during mouse preimplantation development and Van Blerkom et al. (2008) reported that NO produced by mouse or human cumulus cells regulates mitochondrial polarity in the associated oocytes.

In practical terms, there is strong evidence from a number of species that early embryos benefit from being cultured under conditions which will tend to limit ROS formation, for example, low oxygen concentrations $(\sim 5 \%)$, similar to those in the oviduct (Fischer \& Bavister 1993), and in the presence of EDTA; interventions which were shown to be superior, at least in the mouse, in promoting the development of zygotes to blastocysts compared with the ROS scavengers catalase and superoxide dismutase (Orsi \& Leese 2001).

The interest in oxidative stress and the means for its alleviation is one example of the way in which the traditional field of energy metabolism in the early embryo has spawned related areas which have become research topics in their own right. Thus, oxygen and ROS are bound up in a major way with redox status and calcium signaling (Harvey et al. 2002, Lopes et al. 2010); much of the stimulus for research on which has come from studies on oocyte maturation and fertilization (Dumollard et al. 2004) later extended to the early embryo (Dumollard et al. 2009). A common denominator for these biochemical events is obviously provided by their association with the mitochondrion. Van Blerkom et al. (1984) first showed that mitochondria are re-organized during meiotic resumption, and has continued to be a leader in this field (Van Blerkom 2011) alongside the groups of Cummins (2001), Dale and Wilding (Wilding et al. 2009), and Carroll and Swann (Dumollard et al. 2004, 2009, Yu et al. 2010). Impairment of mitochondrial function during preimplantation development can have long-term implications (Igosheva et al. 2010, Wakefield et al. 2011).

Such work parallels the general emergence over the past $\sim 30$ years of molecular cell biology; the placing in a cellular context of research originally concerned with biochemical and molecular events. Mitochondrial events in early embryos are likely to offer rich pickings for researchers, with much to be done; for example, the elegant study of Lane \& Gardner (2005) on the mitochondrial malate-aspartate shuttle is one of few such investigations, and the special properties of mitochondrial DNA (mtDNA; Poulton et al. 2010, St John et al. 2010) provide an interesting backdrop. Thus, in an intriguing hypothesis that unites genetics and metabolism, Bendich (2010) has proposed that germ cells are maintained in a metabolically quiet state in order to limit mitochondrial activity and ROS formation and protect mtDNA, which is extremely unstable and has limited repair capacity, from degradation.

\section{A word about ATP}

It is often reported that 'increased ATP levels' are desirable in order to stimulate embryo development; a viewpoint which considers ATP as a 'store of energy'. In reality, ATP turnover, i.e. the time taken for it all to be replaced, is about $1 \mathrm{~min}$, in the mouse zygote and about $25 \mathrm{~s}$ in the blastocyst (Leese 1991). In other words, ATP has a very short-term lifetime and has to be replaced as soon as it is used, as illustrated by the speed with which aerobic cells, tissues, and organisms die if deprived of oxygen! An even more striking example is given by the elite marathon runner who, it has been calculated, uses a colossal $60 \mathrm{~kg}$ of ATP during a race (Frayn 2010). Moreover, an increase in the steady state level of ATP could arise from an increase in the rate of production, a decrease in the rate of consumption, or some combination of the two. Without considering such details, it is not possible to know the significance of an increase or decrease in ATP content.

\section{Glucose metabolism}

While the rise in glucose consumption during late preimplantation development is well-known in all species studied including the human (Hardy et al. 1989), there has been less discussion on the reason(s) for this. Leese (1995) proposed that acquiring the ability to use glucose and to convert it into lactate enabled the blastocyst to survive the hypoxia that occurs to a varying extent, depending on the species, at implantation. For example, the decidual zone in the rodent is devoid of capillaries and the human conceptus develops in a low oxygen environment during the first trimester (Burton et al. 2010). The potential of early embryos to switch to anaerobic glycolysis was strikingly demonstrated in the rat where Brison \& Leese (1994) showed that blastocyst development could occur in the absence of oxygen or presence of inhibitors of oxidative phosphorylation; cyanide, antimycin-A, and 2,4-dinitrophenol, with related observations; that transient inhibition of oxidative metabolism promotes in vitro development of cattle and pig embryos, reported by Thompson et al. (2000) and Macháty et al. (2001) respectively. However, perhaps the most tantalizing data on glucose metabolism were provided by Lane \& Gardner (1998) on the extent of glycolysis in mouse blastocysts freshly flushed from the uterus and then cultured in vitro (Fig. 2).

The glycolytic rate for fresh embryos: $28 \%$ glucose converted into lactate, increased in only $3 \mathrm{~h}$ in vitro to $\sim 76 \%$ and $\sim 90 \%$ in $6 \mathrm{~h}$. In vivo-derived controls flushed at these time intervals retained a low glycolytic rate. Supplementation of the culture medium with amino acids reduced the $3 \mathrm{~h}$ glycolytic rate to $\sim 55 \%$ and with amino acids and vitamins to $45 \%$ The virtue of using the mouse as a model is the speed with which 


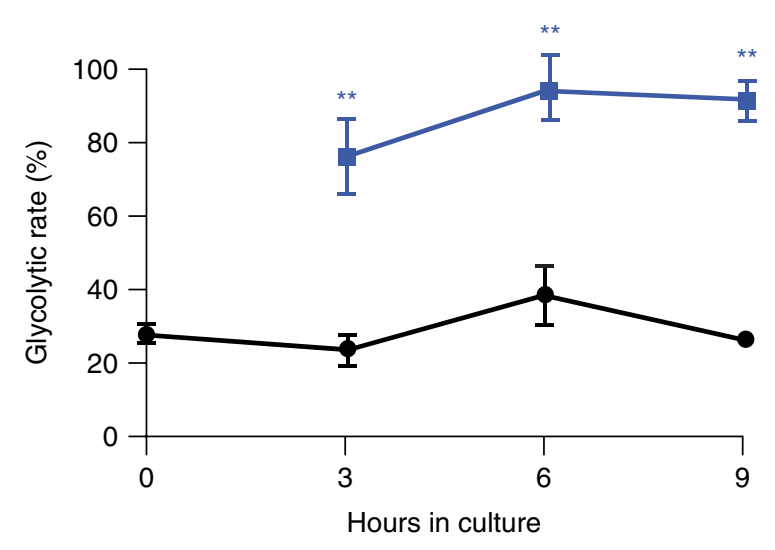

Figure 2 Glycolytic activity of mouse blastocysts immediately following retrieval and following incubation in vitro. Reproduced, with permission, from Lane \& Gardner 1998 Amino acids and vitamins prevent culture-induced metabolic perturbations and associated loss of viability of mouse blastocysts. Human Reproduction 13 991-997. Glycolytic activity of mouse blastocysts after culture in modified mouse tubal fluid (mMTF) medium. $n=20$ blastocysts examined/time-point. Filled square, represents in vivo blastocysts measured immediately after collection; open square, represents blastocysts cultured in mMTF.

**Significantly different to in vivo developed blastocysts $(P<0.01)$.

in vivo-derived embryos can be removed from the oviduct or uterus and placed in culture and hopefully retain their native characteristics compared with large animal models, where the interval between flushing and culture will be much longer and they become, essentially, in vitro embryos by the time they are assayed. Put another way, the data suggest that the high glycolytic rate of in vitro produced embryos and of those derived in vivo but subject to delay between flushing and culture is an artifact which arises upon removal from their natural environment. Strong evidence for this proposition is provided by the follow-up data of Lane \& Gardner (1996) showing that mouse blastocysts with a high glycolytic rate are less viable posttransfer than their low glycolytic counterparts. The same authors developed this concept to consider the nature of stress in preimplantation embryos and the possible means for its alleviation (Lane \& Gardner 2004).

Subtle effects of glucose were proposed by Kaye's group in Australia. It was well-known that mouse preimplantation embryos require at least, a brief exposure to glucose to develop to the blastocyst stage (Chatot et al. 1989, Martin \& Leese 1995, 1999). It was then discovered that glucose was required for morulae to express the glucose transporter GLUT3, essential for blastocyst formation and that glucose was also responsible for expression of the monocarboxylate transporters Jansen et al. (2006, 2008) responsible for coupled transport of a proton with an anion such as pyruvate and lactate; which as well as being involved in the transport of these nutrients, plays a role in $[\mathrm{pH}] \mathrm{i}$ regulation (Fitzharris \& Baltz 2009); indirect evidence for which had earlier been obtained by Gibb et al. (1997) and Butcher et al. (1998). Exploration of the molecular details of this intriguing story has revealed a ROSmediated stress response leading to peroxisomal proliferation (Jansen et al. 2009). In other words, glucose plays a role as a cell-signaling agent as well as potential metabolic substrate. Furthermore, Sutton-McDowall et al. (2010) have described further roles of glucose in the cumulus oocyte complex via metabolism through the pentose phosphate, hexosamine biosynthesis, and polyol pathways.

\section{Amino acids}

This area has been comprehensively reviewed by Sturmey et al. (2008) and a brief account only is given here. Amino acids are now added routinely to human embryo culture media but this was not the case during the early years of IVF. The person most responsible for highlighting the importance of amino acids during preimplantation development was Bavister et al. (1983), especially for rodent embryos with important contributions from Menezo, especially on amino acid metabolism and its relationship with 1-carbon metabolism (Menezo et al. 1989), Rieger et al. 1992, Gardner et al. 1994 and Thompson et al. 1995 on domestic animal embryos, and Hardy and Devreker for human embryos (Devreker et al. 2001). Biggers \& Summers (2008) have provided authoritative accounts on the contemporary picture of amino acids and embryo culture. Originally thought of as mainly precursors of protein synthesis, amino acids are now acknowledged to have multiple roles, beginning with multiple transporters at the plasma membrane (Van Winkle 2001) and continuing downstream (Martin et al. 2003, Kim et al. 2011). For a summary, see Fig. 1 of Sturmey et al. (2008).

\section{Unifying ideas}

\section{Stress-response models}

There have been a number of models and hypotheses which have aimed to provide a unifying framework for considering the metabolism of the oocyte and early embryo. Thus, Lane \& Gardner (2004) focused on the maintenance of homeostasis in the face of environmental stress to the early embryo, especially during cleavage, while Thompson et al. (2002) proposed a stress-induced causal model to show how perturbation of an embryo's environment can lead to changes in phenotype which may be expressed in the fetus and neonate (Fig. 3). The significance of this latter model lies in the immediacy with which metabolism may be modified; well before any changes in gene expression, and potentially leads directly to abnormal fetal growth.

In this context, Rappolee's group (Xie et al. 2011) in a review of the molecular aspects of the stress response in early mammalian development, and contrasting early 

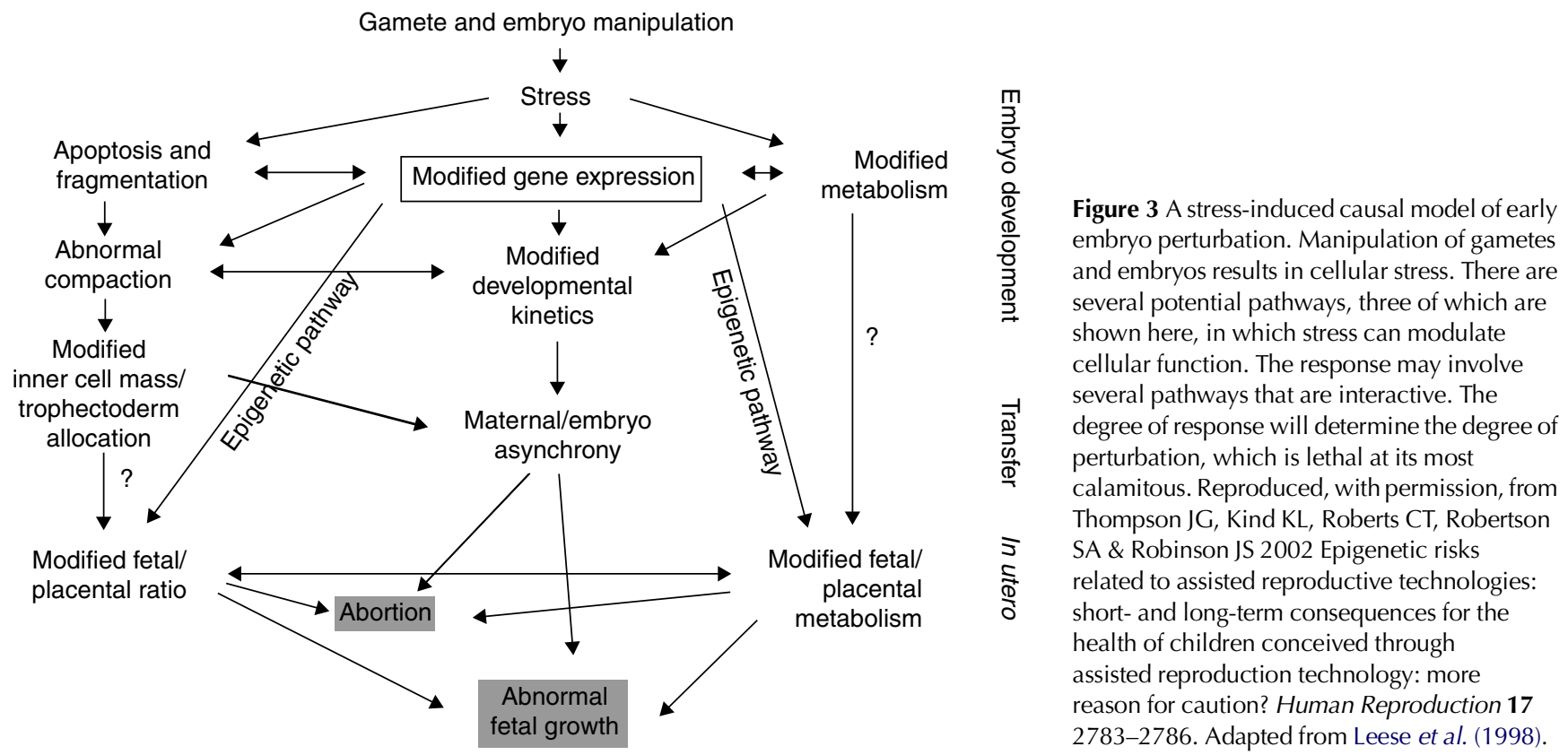

embryos and ES cells, reported that activity of AMP kinase, a 'master-switch' in metabolic homeostasis and response to stress (Chen et al. 2006), showed peak activity only $10-30 \mathrm{~min}$ after stimulation. This review by Xie et al. (2011) is valuable for the way in which it contrasts different stressors and their duration and remarkable for its impressive sweep of the molecular events which follow.

\section{The quiet embryo hypothesis}

The response to stress is a feature of the quiet embryo hypothesis (Leese 2002) but for the most part, this proposition is concerned with the normal state of metabolism during early development. With hindsight, the hypothesis is one statement of the principle that 'nature is thrifty in all its actions'; that living things are thought to be constrained by a tendency to minimize the expenditure of metabolic cost (Srinivasan (2009) paraphrasing Borelli (1680), who asked why humans and animals walk and run the way they do). In the context of the preimplantation embryo, one can, for example, postulate that by minimizing oxygen consumption (i.e. having a quiet metabolism) from the zygote to morula stage, the embryo may limit the formation of ROS and hence the damage they might cause to cellular and molecular processes at this vulnerable time. Further examples of such 'functional' quiet metabolism are considered in Leese et al. (2008).

However, the quiet embryo hypothesis is equally concerned with differences between the metabolism of individual preimplantation embryos in relation to their viability. The metabolic marker in which the relationship with viability is most marked is the 'Amino Acid Profile'; the pattern of depletion or appearance, measured noninvasively, of a close to physiological mixture of amino acids by single embryos. In the case of surplus cleavage-stage human embryos (Houghton et al. 2002) and human zygotes in clinical IVF (Brison et al. 2004) the amino acid profiles of those embryos which reached the blastocyst stage or gave a pregnancy were lower ('quieter') than those which failed to develop. One explanation for these data was provided by Sturmey et al. $(2009 b)$ who measured the extent of DNA damage in individual human embryos at the blastocyst stage and related this to their amino acid profile. Similar studies were carried out in cow and pig preimplantation embryos. For each species, there was a positive relationship between DNA damage and amino acid profile; the more 'noisy' an embryo, the greater was the level of damage and the higher the demand for nutrients such as amino acids and energy for repair processes (discussed in Baumann et al. (2007)). By contrast, those embryos with a quieter metabolism were subject to less damage to the genome, transcriptome, and proteome, or were better equipped to deal with damage when it occurred, and thus devoted fewer resources to what may colloquially be termed 'running repairs'.

Earlier data contributing to the formulation of the quiet embryo hypothesis had been obtained by Conaghan et al. (1993) and Turner et al. (1994) for the uptake of pyruvate by single embryos in conventional IVF (i.e. with ovarian hyperstimulation) and natural cycle IVF respectively (Fig. 4). However, the distribution patterns of pyruvate uptake between viable and nonviable embryos overlap considerably, illustrating the point that different 


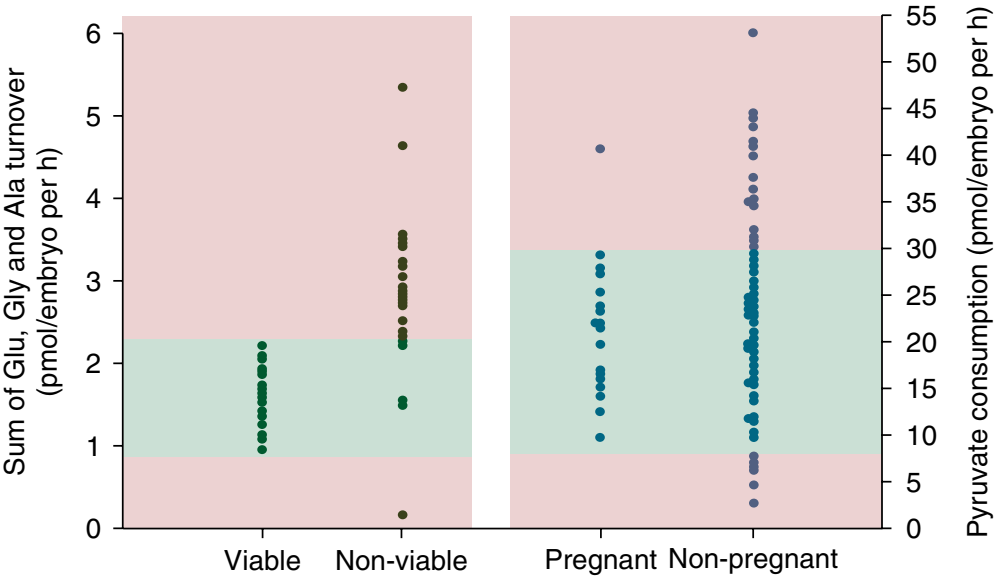

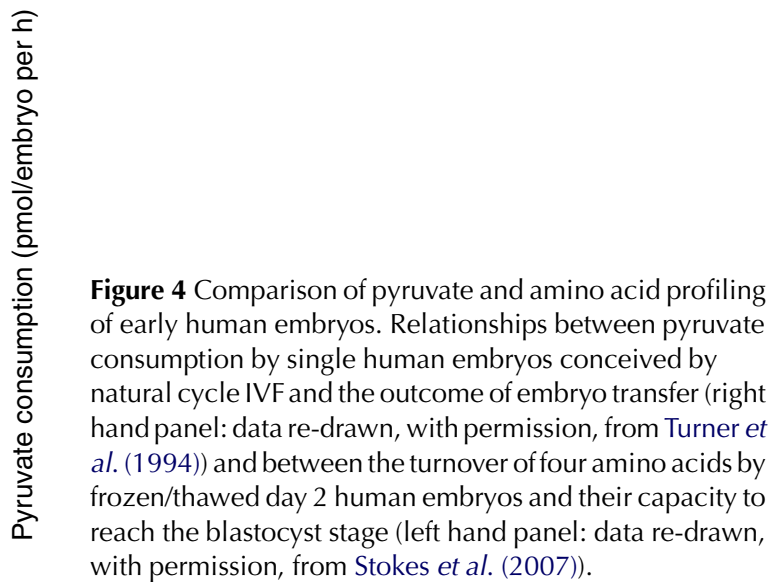

biomarkers will have different distributions and potential for use diagnostically to select single embryos for transfer (Leese et al. 2007).

Recent data by Gardner et al. (2011) showing conclusively that glucose consumption by day 4 or day 5 human embryos which subsequently gave rise to pregnancies following transfer is higher than those which are nonviable apparently contradict the quiet embryo notion. However, as has been discussed, it is a requirement of preimplantation embryos that glucose consumption increases sharply at the blastocyst stage for the embryo to remain viable; entirely consistent with the data of Gardner et al. (2011), and what is required as a test of the quiet embryo hypothesis is the overall metabolic cost of this process; the prediction is that this will be lower in high-quality embryos. By way of analogy, if two people carry out the same piece of physical activity (for example on a treadmill or stationary bicycle and analogous to an embryo increasing its glucose consumption), the fit person (analogous to the healthy embryo) will do so with a lower oxygen uptake.

The challenge is therefore to measure energetic efficiency alongside nutrient uptake and relate the data to developmental competence. The most appropriate marker is oxygen consumption, since most of the ATP required during preimplantation development is derived from oxidative phosphorylation. At the time of writing, there is no consensus on the relationship between oxygen consumption and pregnancy potential. For example, findings for human oocytes were reported by Scott et al. (2008) which indicated that respiration rates neither too high nor too low were consistent with oocyte viability while Tejera et al. (2011) found that human oocytes that generated embryos which implanted had a slightly higher oxygen consumption than those which failed to implant. Ottosen et al. (2007) and Sugimura et al. (2010) both found that cleavage stage, mouse, and pig embryos respectively with higher oxygen consumption were more likely to reach the blastocyst stage while the data of Lopes et al. (2007), given below (Fig. 5), show the distribution of oxygen consumption of single bovine blastocysts which were then transferred to recipients illustrating the wide variation in oxygen uptake between individual embryos and the lack of any simple relationship between respiratory activity and pregnancy potential. All these findings are not surprising bearing in

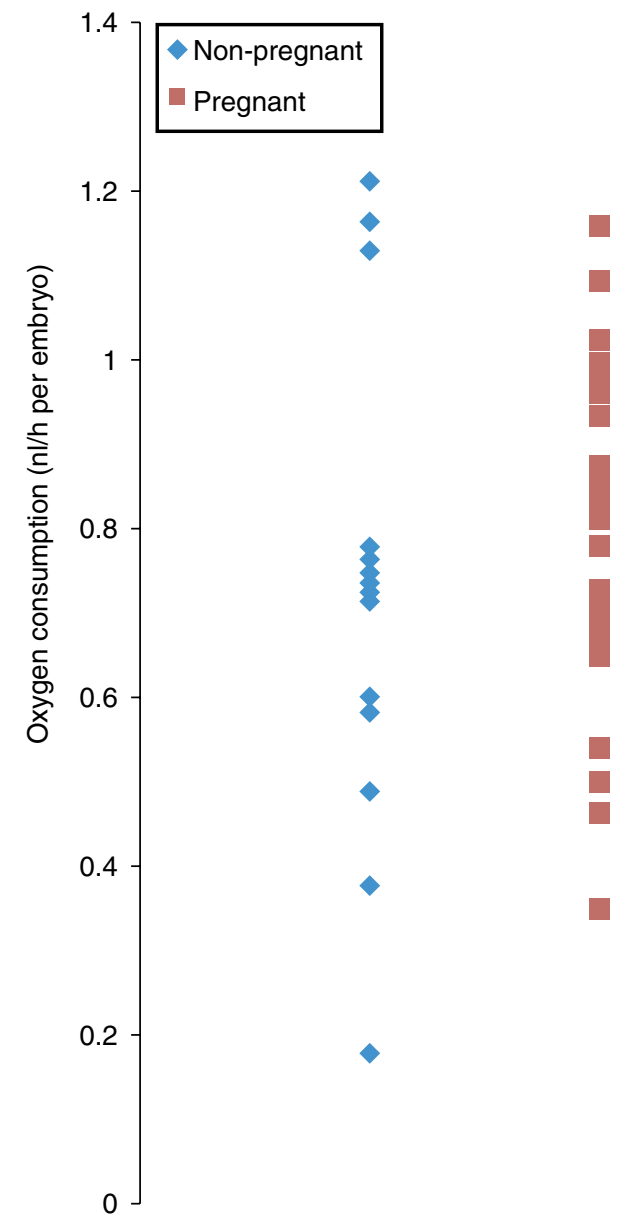

Figure 5 Relationship between respiratory activity ( $\mathrm{nl} / \mathrm{h}$ per embryo) of individual cattle blastocysts produced in vivo and the outcome of embryo transfer. Redrawn from Lopes et al. (2007). Data kindly supplied by Ana Lopes and reproduced with permission. 
mind the data presented earlier on the high proportion of oxygen consumed by nonmitochondrial processes and the requirements of all other cellular functions for ATP.

\section{Conclusion}

To conclude this review, the following is an attempt to update the summary of embryo metabolism presented by Brinster (1973). It is then followed by some future research possibilities.

The Krebs cycle and oxidative phosphorylation provide the main source of energy throughout the preimplantation period. Pyruvate is a central energy substrate during the first cleavage in those species in which energy source requirements of the embryo have been examined, although it is not obligatory for all species (e.g. porcine). Other substrates, notably, amino acids, lactate, and endogenous fatty acids derived from triglyceride, combine with pyruvate to provide embryos with a range of potential energy sources through to, and including, the blastocyst stage. These nutrients have numerous, overlapping, metabolic roles. Prior to the morula stage, glucose consumption and metabolism is low, although some glucose is necessary for intracellular signaling purposes. With blastocyst formation, large increases in oxygen consumption and the uptake and incorporation of carbon occur and there is a sharp increase in glycolysis, at least in vitro. The embryo goes from a relatively inactive metabolic tissue at ovulation to a rapidly metabolizing tissue at implantation. Mitochondria play a pivotal role during early development, as well as providing a cellular focus for metabolic events. We are almost totally ignorant of the metabolism of preimplantation embryos in situ (in the oviduct and uterus) and understanding of signal transduction within the embryo is in its infancy as is the molecular dialog between embryos in culture and with the maternal tract in vivo.

\section{Future research questions}

1. What is the relationship between metabolism and development: what are the metabolic efficiencies of the key molecular/biochemical process required for preimplantation development?

2. What is the metabolism of the early embryo in vivo? Metabolic differences between in vivo and in vitroderived embryos and the superior quality of the former are well-known (Thompson 1997) but we are ignorant of the metabolism of embryos within the female reproductive tract. One experimental approach might involve imaging embryos through the transparent wall of the mouse ampulla.

3 . What is the nature of the molecular dialog between the embryo and the female tract and between individual embryos in culture?

4. What are the mechanisms by which perturbation of metabolism periconceptually compromises the health of the offspring?

\section{Declaration of interest}

The author declares that there is no conflict of interest that could be perceived as prejudicing the impartiality of the review reported.

\section{Funding}

This review did not receive any specific grant from any funding agency in the public, commercial or not-for-profit sector.

\section{Acknowledgements}

I thank Dr Roger Sturmey for invaluable comments on earlier drafts of the manuscript and Lynette Scott, tragically deceased, for inspiring conversations over many years.

\section{References}

Alexiou M \& Leese HJ 1992 Purine utilisation, de novo synthesis and degradation in mouse preimplantation embryos. Development 114 185-192.

Alexiou M \& Leese HJ 1994 Enzymes of purine salvage and catabolism in the mouse preimplantation embryo measured by high performance liquid chromatography. Journal of Reproduction and Fertility 101 151-158. (doi:10.1530/jrf.0.1010151)

Bain NT, Madan P \& Betts DH 2011 The early embryo response to intracellular reactive oxygen species is developmentally regulated. Reproduction, Fertility, and Development 23 561-575. (doi:10.1071/ RD10148)

Barker DJ 2004 The developmental origins of adult disease. Journal of the American College of Nutrition 23 (Suppl 6) 588S-595S.

Barnett DK \& Bavister BD 1996 What is the relationship between the metabolism of preimplantation embryos and their developmental competence? Molecular Reproduction and Development 43 105-133. (doi:10. 1002/(SICI)1098-2795(199601)43:1 < 105::AID-MRD13>3.0.CO;2-4)

Baumann CG, Morris DG, Sreenan JM \& Leese HJ 2007 The quiet embryo hypothesis: molecular characteristics favoring viability. Molecular Reproduction and Development 74 1345-1353. (doi:10.1002/mrd. 20604)

Bavister BD, Leibfried ML \& Lieberman G 1983 Development of preimplantation embryos of the golden hamster in a defined culture medium. Biology of Reproduction 28 235-247. (doi:10.1095/biolreprod 28.1.235)

Bendich AJ 2010 Mitochondrial DNA, chloroplast DNA, and the origins of development in eukaryotic organisms. Biology Direct 542. (doi:10.1186/1745-6150-5-42)

Biggers JD \& Stern S 1973 Metabolism of the preimplantation mammalian embryo. Advances in Reproductive Physiology 6 1-59.

Biggers JD \& Summers MC 2008 Choosing a culture medium: making informed choices. Fertility and Sterility 90 473-483. (doi:10.1016/ j.fertnstert.2008.08.010)

Birket MJ, Orr AL, Gerencser AA, Madden DT, Vitelli C, Swistowski A, Brand MD \& Zeng X 2011 A reduction in ATP demand and mitochondrial activity with neural differentiation of human embryonic stem cells. Journal of Cell Science 124 348-358. (doi:10.1242/jcs. 072272)

Borelli JA 1680 On the movement of animals (De Motu Animalium, pars prima) Springer-Verlag, p 152 (translated by P Maquet 1989).

Brinster RL 1973 Nutrition and metabolism of the ovum, zygote and blastocyst. In Handbook of Physiology, pp 165-185. Eds RO Greep\& ED Astwood. Washington, DC, USA: American Physiological Society.

Brison DR \& Leese HJ 1994 Blastocoel cavity formation by preimplantation rat embryos in the presence of cyanide and other inhibitors of oxidative phosphorylation. Journal of Reproduction and Fertility 101 305-309. (doi:10.1530/jrf.0.1010305) 
Brison DR, Houghton FD, Falconer D, Roberts SA, Hawkhed J, Humpherson PG, Lieberman BA \& Leese HJ 2004 Identification of viable embryos in IVF by non-invasive measurement of amino acid turnover. Human Reproduction 19 2319-2324. (doi:10.1093/humrep/ deh409)

Burton GJ, Jauniaux E \& Charnock-Jones DS 2010 The influence of the intrauterine environment on human placental development. International Journal of Developmental Biology 54 303-311. (doi:10.1387/ ijdb.082764gb)

Butcher L, Coates A, Martin KL, Rutherford AJ \& Leese HJ 1998 Metabolism of pyruvate by the early human embryo. Biology of Reproduction 58 1054-1056. (doi:10.1095/biolreprod58.4.1054)

Ceelen $M$, van Weissenbruch MM, Vermeiden JP, van Leeuwen FE \& Delemarre-van de Waal HA 2008 Cardiometabolic differences in children born after IVF: follow-up study. Journal of Clinical Endocrinology and Metabolism 93 1682-1688. (doi:10.1210/jc.2007-2432)

Chason RJ, Csokmay J, Segars JH, DeCherney AH \& Armant DR 2011 Environmental and epigenetic effects upon preimplantation embryo metabolism and development. Trends in Endocrinology and Metabolism 22 412-420. (doi:10.1016/j.tem.2011.05.005)

Chatot CL, Ziomek CA, Bavister BD, Lewis JL \& Torres I 1989 An improved culture medium supports development of random-bred 1-cell mouse embryos in vitro. Journal of Reproduction and Fertility 86 679-688. (doi:10.1530/jrf.0.0860679)

Chen J, Hudson E, Chi MM, Chang AS, Moley KH, Hardie DG \& Downs SM 2006 AMPK regulation of mouse oocyte meiotic resumption in vitro. Developmental Biology 291 227-238. (doi:10.1016/j.ydbio.2005.11. 039)

Conaghan J, Hardy K, Handyside AH, Winston RML \& Leese HJ 1993 Selection criteria for human embryo transfer: a comparison of pyruvate uptake and morphology. Journal of Assisted Reproduction and Genetics 10 21-30. (doi:10.1007/BF01204436)

Cummins JM 2001 Mitochondria: potential roles in embryogenesis and nucleocytoplasmic transfer. Human Reproduction Update 7 217-228. (doi:10.1093/humupd/7.2.217)

Devreker F, Hardy K, Van den Bergh M, Vannin AS, Emiliani S \& Englert Y 2001 Amino acids promote human blastocyst development in vitro. Human Reproduction 16 749-756. (doi:10.1093/humrep/16.4.749)

Donnay I \& Leese HJ 1999 Embryo metabolism during the expansion of the bovine blastocyst. Molecular Reproduction and Development 53 171-178. (doi:10.1002/(SICI)1098-2795(199906)53:2<171::AID-MRD6 $>3.0 . \mathrm{CO} ; 2-\mathrm{F})$

Downs SM \& Hudson ED 2000 Energy substrates and the completion of spontaneous meiotic maturation. Zygote 8 339-351. (doi:10.1017/ S0967199400001131)

Dumollard R, Marangos P, Fitzharris G, Swann K, Duchen M \& Carroll J 2004 Sperm-triggered $\left[\mathrm{Ca}^{2+}\right]$ oscillations and $\mathrm{Ca}^{2+}$ homesostasis in the mouse egg have an absolute requirement for mitochondrial ATP production. Development 131 3057-3067. (doi:10.1242/dev.01181)

Dumollard R, Carroll J, Duchen MR, Campbell K \& Swann K 2009 Mitochondrial function and redox state in mammalian embryos. Seminars in Cell \& Developmental Biology 20 346-353. (doi:10.1016/ j.semcdb.2008.12.013)

Dunning KR, Cashman K, Russell DL, Thompson JG, Norman RJ \& Robker RL 2010 Beta-oxidation is essential for mouse oocyte developmental competence and early embryo development. Biology of Reproduction 83 909-918. (doi:10.1095/biolreprod.110.084145)

Ferguson EM \& Leese HJ 2006 A potential role for triglyceride as an energy source during bovine oocyte maturation and early embryo development. Molecular Reproduction and Development 73 1195-1201. (doi:10. 1002/mrd.20494)

Fischer B \& Bavister BD 1993 Oxygen tension in the oviduct and uterus of rhesus monkeys, hamsters and rabbits. Journal of Reproduction and Fertility 99 673-679. (doi:10.1530/jrf.0.0990673)

FitzHarris G \& Baltz JM 2009 Regulation of intracellular pH during oocyte growth and maturation in mammals. Reproduction 138 619-627. (doi:10.1530/REP-09-0112)

Frayn KN 2010 Metabolic Regulation: A human perspective. Blackwell Publishing.

Fridhandler I, Hafez ESE \& Pincus G 1957 Developmental changes in the respiratory activity of rabbit ova. Experimental Cell Research 13 132-139. (doi:10.1016/0014-4827(57)90054-X)
Gardner DK, Lane M, Spitzer A \& Batt PA 1994 Enhanced rates of cleavage and development for sheep zygotes cultured to the blastocyst stage in vitro in the absence of serum and somatic cells: amino acids, vitamins and culturing embryos in groups stimulate development. Biology of Reproduction 50 390-400. (doi:10.1095/biolreprod50.2.390)

Gardner DK, Wale PL, Collins R \& Lane M 2011 Glucose consumption of single post-compaction human embryos is predictive of embryo sex and live birth outcome. Human Reproduction 26 1981-1986. (doi:10.1093/ humrep/der143)

Gibb CA, Poronnik P, Day ML \& Cook DI 1997 Control of cytosolic pH in two-cell mouse embryos: roles of $\mathrm{H}(+)$-lactate cotransport and $\mathrm{Na}^{+} / \mathrm{H}^{+}$ exchange. American Journal of Physiology 273 C404-C419.

Gupta S, Banerjee J \& Agarwal A 2006 The impact of reactive oxygen species on early human embryos: a systematic review of the literature. Embryo Talk 1 87-94.

Gilbert SF \& Epel D 2009 Ecological Developmental Biology: Integrating Epigenetics, Medicine, and Evolution. Sunderland, Massachusetts, USA: Sinauer Associates, Inc.

Hardy K, Hooper MAK, Handyside AH, Rutherford AJ, Winston RML \& Leese HJ 1989 Non-invasive measurement of glucose and pyruvate uptake by individual human oocytes and preimplantation embryos. Human Reproduction 4 188-191.

Harvey AJ, Kind KL \& Thompson JG 2002 REDOX regulation of early embryo development. Reproduction 123 479-486. (doi:10.1530/rep.0. 1230479)

Herst PM \& Berridge MV 2007 Cell surface oxygen consumption: a major contributor to cellular oxygen consumption in glycolytic cell lines. Biochimica et Biophysica Acta 1767 170-177. (doi:10.1016/j.bbabio. 2006.11.018)

Houghton FD, Thompson JG, Kennedy CJ \& Leese HJ 1996 Oxygen consumption and energy metabolism of the early mouse embryo. Molecular Reproduction and Development 44 476-485. (doi:10.1002/ (SICI) 1098-2795(199608)44:4<476::AID-MRD7> 3.0.CO;2-I)

Houghton FD, Hawkhead JA, Humpherson PG, Hogg JE, Balen AH, Rutherford AJ \& Leese HJ 2002 Non-invasive amino acid turnover predicts human embryo developmental capacity. Human Reproduction 17 999-1005. (doi:10.1093/humrep/17.4.999)

Houghton FD, Humpherson PG, Hawkhead JA, Hall CJ \& Leese HJ 2003 $\mathrm{Na}^{+}, \mathrm{K}^{+}$ATPase activity in the human and bovine preimplantation embryo. Developmental Biology 263 360-366. (doi:10.1016/j.ydbio. 2003.07.014)

Igosheva N, Abramov AY, Poston L, Eckert JJ, Fleming TP, Duchen MR \& McConnell J 2010 Maternal diet-induced obesity alters mitochondrial activity and redox status in mouse oocytes and zygotes. PLOS ONE 9 e10074. (doi:10.1371/journal.pone.0010074)

Jansen S, Esmaeilpour T, Pantaleon M \& Kaye PL 2006 Glucose affects monocarboxylate cotransporter (MCT) 1 expression during mouse preimplantation development. Reproduction 131 469-479. (doi:10. 1530/rep.1.00953)

Jansen S, Pantaleon M \& Kaye PL 2008 Characterisation and regulation of monocarboxylate cotransporters Slc16a7 and Slc16a3 in preimplantation mouse embryos. Biology of Reproduction 79 84-92. (doi:10.1095/ biolreprod.107.066811)

Jansen S, Cashman K, Thompson JG, Pantaleon M \& Kaye PL 2009 Glucose deprivation, oxidative stress and peroxisome proliferator-activated receptor- $\alpha$ (PPARA) cause peroxisome proliferation in preimplantation mouse embryos. Reproduction 138 493-505. (doi:10.1530/REP-090038)

Johnson MH \& Nasr-Esfahani MH 1994 Radical solutions and cultural problems: could free oxygen radicals be responsible for the impaired development of preimplantation mammalian embryos in vitro? BioEssays: News and Reviews in Molecular, Cellular and Developmental Biology 16 31-38.

Jungheim ES, Louden ED, Chi MM, Frolova AI, Riley JK \& Moley KH 2011 Preimplantation exposure of mouse embryos to palmitic acid results in fetal growth restriction followed by catch-up growth in the offspring. Biology of Reproduction 85 678-683. (doi:10.1095/biolreprod.111. 092148)

Kane MT 1987 Minimal nutrient requirements for culture of one-cell rabbit embryos. Biology of Reproduction 37 775-778. (doi:10.1095/biolre$\operatorname{prod} 37.4 .775)$ 
Kane MT 1979 Fatty acids as energy sources for culture of one-cell rabbit ova to viable morulae. Biology of Reproduction 20 323-332. (doi:10. 1095/biolreprod20.2.323)

Kane MT, Morgan PM \& Coonan C 1997 Peptide growth factors and preimplantation development. Human Reproduction Update 3 137-157.

Kim J, Burghardt EC, Wu G, Johnson GA, Spencer TE \& Bazer FW 2011 Select nutrients in the ovine uterine lumen. IX. Differential effects of arginine, leucine, glutamine and glucose on interferon tau, ornithine decarboxylase and nitric oxide synthase in the ovine conceptus. Biology of Reproduction 84 1139-1147. (doi:10.1095/biolreprod.110.088153)

Lane M \& Gardner DK 1996 Selection of viable mouse blastocysts prior to transfer using metabolic criterion. Human Reproduction 11 1975-1996.

Lane M \& Gardner DK 1998 Amino acids and vitamins prevent cultureinduced metabolic perturbations and associated loss of viability of mouse blastocysts. Human Reproduction 13 991-997. (doi:10.1093/ humrep/13.4.991)

Lane M \& Gardner DK 2004 Understanding cellular disruptions during early embryo development that perturb viability and fetal development. Reproduction, Fertility, and Development 17 371-378. (doi:10.1071/ RD04102)

Lane M \& Gardner DK 2005 Mitochondrial malate-aspartate shuttle regulates mouse embryo nutrient consumption. Journal of Biological Chemistry 280 18361-18367. (doi:10.1074/jbc.M500174200)

Leese HJ 1991 Metabolism of the preimplantation mammalian embryo. In Oxford Reviews of Reproductive Biology. Ed SR Milligan, vol 13, pp 35-72. Oxford University Press.

Leese HJ 1995 Metabolic control during preimplantation mammalian development. Human Reproduction Update 1 63-72. (doi:10.1093/ humupd/1.1.63)

Leese HJ 2002 Quiet please: do not disturb. A hypothesis of embryo metabolism and viability. BioEssays: News and Reviews in Molecular, Cellular and Developmental Biology 24 845-849.

Leese HJ \& Whittall H 2001 Regulation of the transition from research to clinical practice in human assisted conception. Human Fertility 4 172-176. (doi:10.1080/1464727012000199262)

Leese HJ, Donnay I \& Thompson JG 1998 Human assisted conception; a cautionary tale: lessons from domestic animals. Human Reproduction $\mathbf{1 3}$ (Suppl 4) 184-202.

Leese HJ, Sturmey RG, Baumann CJ \& McEvoy TG 2007 Embryo viability and metabolism: obeying the quiet rules. Human Reproduction 22 3047-3050. (doi:10.1093/humrep/dem253)

Leese HJ, Baumann CG, Brison DR, McEvoy TG \& Sturmey RG 2008 Metabolism of the viable mammalian embryo: quietness revisited. Molecular Human Reproduction 14 667-672. (doi:10.1093/molehr/ gan065)

Lopes AS, Madsen SE, Ramsing NB, Løvendahl P, Greve T \& Callesen H 2007 Investigation of respiration of individual bovine embryos produced in vivo and in vitro and correlation with viability following transfer. Human Reproduction 22 558-566. (doi:10.1093/humrep/del404)

Lopes AS, Lane M \& Thompson JG 2010 Oxygen consumption and ROS production are increased at the time of fertilization and cell cleavage in bovine zygotes. Human Reproduction 25 2762-2773. (doi:10.1093/ humrep/deq221)

Macháty Z, Thompson JG, Abeydeera LR, Day BN \& Prather RS 2001 Inhibitors of mitochondrial ATP production at the time of compaction improve development of in vitro produced porcine embryos. Molecular Reproduction and Development 58 39-44. (doi:10.1002/10982795(200101)58:1 <39::AID-MRD6 > 3.0.CO;2-B)

Manes C \& Lai NC 1995 Nonmitochondrial oxygen utilization by rabbit blastocysts and surface production of superoxide radicals. Journal of Reproduction and Fertility 104 69-75. (doi:10.1530/jrf.0.1040069)

Manser R, Leese H \& Houghton F 2004 Effect of inhibition of nitric oxide production on mouse preimplantation embryo development and metabolism. Biology of Reproduction 71 528-533. (doi:10.1095/ biolreprod.103.025742)

Martin K \& Leese HJ 1995 The role of glucose in mouse preimplantation embryo development. Molecular Reproduction and Development 40 436-443. (doi:10.1002/mrd.1080400407)

Martin KL \& Leese HJ 1999 Role of developmental factors in the switch from pyruvate to glucose as the major exogenous energy substrate in the preimplantation mouse embryo. Reproduction, Fertility, and Development 11 425-433. (doi:10.1071/RD97071)
Martin PM, Sutherland AE \& Van Winkle LJ 2003 Amino acid transport regulates blastocyst implantation. Biology of Reproduction 69 1101-1108. (doi:10.1095/biolreprod.103.018010)

McKeegan PJ \& Sturmey RG 2012 The role of fatty acids in oocyte and early embryo development. Reproduction, Fertility, and Development 24 59-67. (doi:10.1071/RD11907)

Menezo Y, Khatchadourian C, Gharib A, Hamidi J, Greenland T \& Sarda N 1989 Regulation of $S$-adenosyl methionine synthesis in the mouse embryo. Life Sciences 44 1601-1609. (doi:10.1016/00243205(89)90455-4)

Mills RM \& Brinster RL 1967 Oxygen consumption of preimplantation mouse embryos. Experimental Cell Research 47 337-344. (doi:10.1016/ 0014-4827(67)90236-4)

Navarette-Santos A, Ramin N, Tonack S \& Fischer B 2008 Cell lineagespecific signaling of insulin and insulin-like growth factor I in rabbit blastocysts. Endocrinology 149 515-524.

O'Brien PMS, Wheeler T \& Barker DJP (Eds) 1999 Fetal Programming: Influences on Development and Disease in Later Life. RCOG Press.

O'Neill C 2008 The potential roles for embryotrophic ligands in preimplantation embryo development. Human Reproduction Update 14 275-288. (doi:10.1093/humupd/dmn002)

Orsi NM \& Leese HJ 2001 Protection against reactive oxygen species during mouse preimplantation embryo development: role of EDTA, oxygen tension, catalase, superoxide dismutase and pyruvate. Molecular Reproduction and Development 59 44-53. (doi:10.1002/mrd.1006)

Ottosen LDM, Hindkjaer J, Lindenberg S \& Ingerslev HJ 2007 Murine preembryo oxygen consumption and developmental competence. Journal of Assisted Reproduction and Genetics 24 359-365. (doi:10.1007/s10815007-9138-5)

Poulton J, Chiaratti MR, Meirelles FV, Kennedy S, Wells D \& Holt IJ 2010 Transmission of mitochondrial DNA diseases and ways to prevent them. PLoS Genetics 6 e1001066. (doi:10.1371/journal.pgen.1001066)

Rieger D, Loskutoff NM \& Betteridge KJ 1992 Developmentally related changes in the metabolism of glucose and glutamine by cattle embryos produced and co-cultured in vitro. Journal of Reproduction and Fertility 95 585-595. (doi:10.1530/jrf.0.0950585)

SACN 2011 The influence of maternal, fetal and child nutrition on the development of chronic disease in later life. London: The Stationery Office.

Sahin E \& DePinho RA 2010 Linking functional decline of telomeres, mitochondria and stem cells during ageing. Nature 464 520-528. (doi:10.1038/nature08982)

Scott L, Bernsten J, Davies D, Gundersen J, Hill J \& Ramsing N 2008 Innovative techniques in human embryo viability assessment. Human oocyte respiration-rate measurement - potential to improve oocyte and embryo selection? Reproductive Biomedicine Online 17 461-469. (doi:10.1016/S1472-6483(10)60232-5)

Srinivasan M 2009 Optimal speeds for walking and running, and walking on a moving walkway. Chaos 19 026112. (doi:10.1063/1. 3141428)

St John JC, Facucho-Oliveria J, Jiang Y, Kelly R \& Salah R 2010 Mitochondrial DNA transmission, replication and inheritance: a journey from the gamete through the embryo and into offspring and embryonic stem cells. Human Reproduction Update 16 488-509. (doi:10.1093/ humupd/dmq002)

Stokes PJ, Hawkhead JA, Fawthrop RK, Picton HM, Sharma V, Leese HJ \& Houghton FD 2007 Metabolism of human embryos following cryopreservation: implications for the safety and selection of embryos for transfer in clinical IVF. Human Reproduction 22 829-835. (doi:10.1093/humrep/ del447)

Storey B 2008 Mammalian sperm metabolism: oxygen and sugar, friend or foe. International Journal of Developmental Biology 52 427-437. (doi:10.1387/ijdb.072522bs)

Sturmey RG, O'Toole PJ \& Leese HJ 2006 Fluorescence resonance energy transfer analysis of mitochondrial:lipid association in the porcine oocyte. Reproduction 132 829-837. (doi:10.1530/REP-06-0073)

Sturmey RG, Brison DR \& Leese HJ 2008 Innovative techniques in human embryo viability assessment: assessing embryo viability by measurement of amino acid turnover. Reproductive Biomedicine Online 17 486-496. (doi:10.1016/S1472-6483(10)60234-9) 
Sturmey RG, Reiss A, Leese HJ \& McEvoy TG 2009a Role of fatty acids in energy provision during oocyte maturation and early embryo development. Reproduction in Domestic Animals 44 (Suppl 3) 50-58. (doi:10. 1111/j.1439-0531.2009.01402.x)

Sturmey RG, Hawkhead J, Barker EA \& Leese HJ $2009 \mathrm{~b}$ DNA damage and metabolic activity in the preimplantation embryo. Human Reproduction 24 81-91. (doi:10.1093/humrep/den346)

Suguwara S \& Umezu M 1961 Studies on the metabolism of the mammalian ova. II. Oxgyen consumption on the cleaved ova of the rat. Tohoku Journal of Agricultural Research 12 17-28.

Sugimura S, Yokoo M, Yamanaka K, Kawahara M, Moriyasu S, Wakai T, Nagai T, Abe H \& Sato E 2010 Anomolous oxygen consumption in porcine somatic cell nuclear transfer embryos. Cell Programming 12 463-474.

Sutton-McDowall ML, Gilchrist RB \& Thompson JG 2010 The pivotal role of glucose metabolism in determining oocyte developmental competence. Reproduction 139 685-695. (doi:10.1530/REP-09-0345)

Tejera A, Herrero J, de Los Santos MJ, Garrido N, Ramsing N \& Meseguer M 2011 Oxygen consumption is a quality marker for human oocyte competence conditioned by ovarian stimulation regimens. Fertility and Sterility 96 618-623. (doi:10.1016/j.fertnstert.2011.06.059)

Thompson JG 1997 Comparison between in vivo-derived and in vitroproduced pre-elongations embryos from domestic ruminants. Reproduction, Fertility, and Development 9 341-354. (doi:10.1071/R96079)

Thompson JG, Gardner DK, Pugh PA, McMillan WH \& Tervit HR 1995 Lamb birth weight is affected by culture system utilized during in vitro pre-elongation development of ovine embryos. Biology of Reproduction 53 1385-1391. (doi:10.1095/biolreprod53.6.1385)

Thompson JG, McNaughton C, Gasparrini B, McGowan LT \& Tervit HR 2000 Effect of inhibitors and uncouplers of oxidative phosphorylation during compaction and blastulation of bovine embryos culture ion vitro. Journal of Reproduction and Fertility 118 47-55. (doi:10.1530/reprod/ 118.1.47)

Thompson JG, Kind KL, Roberts CT, Robertson SA \& Robinson JS 2002 Epigenetic risks related to assisted reproductive technologies: short- and long-term consequences for the health of children conceived through assisted reproduction technology: more reason for caution? Human Reproduction 17 2783-2786. (doi:10.1093/humrep/17.11.2783)

Trimarchi JR, Liu L, Porterfield DM, Smith PJ \& Keefe DL 2000 Oxidative phosphorylation-dependent and -independent oxygen consumption by individual preimplantation mouse embryos. Biology of Reproduction 62 1866-1874. (doi:10.1095/biolreprod62.6.1866)

Turner K, Martin KL, Woodward BJ, Lenton EA \& Leese HJ 1994 Comparison of pyruvate uptake by embryos derived from conception and non-conception natural cycles. Human Reproduction 9 2362-2366.
Van Blerkom J 2011 Mitochondrial function in the human oocyte and embryo and their role in developmental competence. Mitochondrion 11 797-813. (doi 10.1016/j.mito2010.09.012)

Van Blerkom J \& Runner MN 1984 Mitochondrial reorganization during resumption of arrested meiosis in the mouse oocyte. American journal of Anatomy 171 335-355. (doi: 10.1002/aja.1001710309)

Van Blerkom J, David P \& Thalhammer V 2008 Regulation of mitochondrial polarity in mouse and human oocytes: the influence of cumulus derived nitric oxide. Molecular Human Reproduction 14 431-446. (doi:10.1093/ molehr/gan037)

Van Hoeck V, Sturmey RG, Bermejo-Alvarez P, Rizos D, Gutierrez-Adan A, Leese HJ, Bols PE \& Leroy JL 2011 Elevated non-esterified fatty acid concentration during bovine oocyte maturation compromise early embryo physiology. PLoS ONE 6 e23183. (doi:10.1371/journal.pone. 0023183)

Van Winkle LJ 2001 Amino acid transport regulation and early embryo development. Biology of Reproduction 64 1-12. (doi:10.1095/biolreprod64.1.1)

Varum S, Rodrigues AS, Moura MB, Momcilovic O, Easley CA, RamalhoSantos J, Van Houten B \& Schatten G 2011 Energy metabolism in human pluripotent stem cells and their differentiated counterparts. PLOS ONE 6 e20914. (doi:10.1371/journal.pone.0020914)

Wakefield SL, Lane M \& Mitchell M 2011 Impaired mitochondrial function in the preimplantaiton embryo perturbs fetal and placental development in the mouse. Biology of Reproduction 84 572-580. (doi:10.1095/ biolreprod.110.087262)

Watkins AJ \& Fleming TP 2009 Blastocyst environment and its influence on offspring cardiovascular health: the heart of the matter. Journal of Anatomy 215 52-59. (doi:10.1111/j.1469-7580.2008.01033.x)

Wilding M, Coppola G, Dale B \& Di Matteo L 2009 Mitochondria and human preimplantation development. Reproduction 137 619-624. (doi:10.1530/REP-08-0444)

Xie Y, Awonuga AO, Zhou S, Puscheck EE \& Rappolee DA 2011 Interpreting the stress response of early mammalian embryos and their stem cells. International Review of Cell and Molecular Biology 287 43-95.

Yu Y, Dumollard R, Rossbach A, Lai FA \& Swann K 2010 Redistribution of mitochondria leads to bursts of ATP production during spontaneous mouse oocyte maturation. Journal of Cellular Physiology 224 672-680. (doi:10.1002/jcp.22171)

Received 19 December 2011

First decision 2 February 2012

Accepted 7 March 2012 